\title{
TWO NEW FORMS OF HILBERT INTEGRAL INEQUALITY
}

\section{E. AZAR}

Abstract. In this paper we obtain two new forms of the Hilbert inequality. The first form is a sharper form of the classical Hilbert inequality and is connected to Hardy inequality. In the second one we introduce a differential form of Hilbert inequality.

Mathematics subject classification (2010): 26D15.

Keywords and phrases: Hilbert's integral inequality, Hölder inequality, Hardy inequality.

\section{REFERENCES}

[1] A. ČIŽMEŠIJA, M. KRnIĆ, J. PEČARIĆ, General Hilbert's inequality with non-conjugate parameters, Math. Inequal. Appl. 11 (2008), 237-269.

[2] G. H. Hardy, J. E. Littlewood, And G. Polya, Inequalities, Cambridge Univ. Press, London, 1952.

[3] A. Kufner, L. Maligranda, L.-E. Persson, The prehistory of the Hardy inequality, Amer. Math. Monthly, 113(2006), 715-732.

[4] A. Kufner, L. Maligranda, L. E. Persson, The Hardy inequality - About its history and some related results, Vydavatelský servis, Pilsen, 2007.

[5] M. KRnIĆ, J. PEČARIĆ, General Hilbert's and Hardy's inequalities, Math. Inequal. Appl. 8 (2005), $29-52$.

[6] M. Krnić, J. PeČARIĆ, Extension of Hilbert's inequality, J. Math. Anal. Appl. 324 (2006), 150-160.

[7] M. KRNIĆ, A refined discrete Hilbert inequality via the Hermite-Hadamard inequality, Comput. Math. Appl. 63 (2012), 1587-1596.

[8] G. Mingzhe, B. Yang, On the extended Hilbert's inequality, Proc. Amer. Math. Soc. 126 (1998), $751-759$.

[9] B. Yang, I. Brnetić, M. Krnić And J. PeČARIĆ, Generalization of Hilbert and Hardy-Hilbert integral inequalities, Math. Ineq. and Appl. 8 (2) (2005) 259-272.

[10] B. YANG, T. M. RASSIAS, On the way of weight coefficients and research for the Hilbert-type inequalities, Math. Inequal. Appl. 6 (2003), 625-658. 